\title{
Bruce Springsteen, Cultural Studies, and the Runaway American Dream
}

\author{
Kenneth Womack, Jerry Zolten and Mark Bernhard \\ Surrey, England: Ashgate, 2012 \\ ISBN: 9781409404972 \\ RRP: $£ 20.00$ (GBP)
}

\section{David Cashman \\ Southern Cross University \\ david.cashman@scu.edu.au}

Bruce Springsteen is a contradiction. As an American hero and anti-hero who writes songs that are simple and accessible and yet of great depth and complexity, it is not surprising that he has attracted a significant amount of academic attention (Rhodes 2004, Cullen 2005, Kirkpatrick 2007, Auxier and Anderson 2008, Symynlywicz 2008, Masciotra 2010). Springsteen has created some iconic moments in popular music culture, such as the raised fist, the pounding of the anthemic Born in the U.S.A. and the adoption of Springsteen by the Reagan republicans. With a career spanning four decades, Springsteen is one of America's most senior and important rockers consistently releasing successful albums within the fickle world of popular music. Among the recent academic publications on this significant artist is, Bruce Springsteen, Cultural Studies and the Runaway American Dream, a collection of fourteen essays addressing key concepts within Springsteen's body of work. This largely successful collection is a testament to Springsteen's influence and continuing popularity, and a significant addition to the academic literature addressing Springsteen.

Like Elvis Presley and Bob Dylan, to whom Springsteen is compared in Howard Kramer's introduction, Springsteen's work has changed over the decades as he has reinvented himself several times. His topics have ranged from a young man's dream of cars and women to the darker nostalgia of an older artist. Yet through this long career, several topic areas have remained constant. The image of the working-class hero, blue jeans and baseball cap, permeates much of Springsteen's work and has formed much of his fan base. Part one of this collection addresses Springsteen and the working class. Springsteen's heroes across his career have nearly always been masculine, though women play a strong part in many of his songs. Part two discusses gender in the dominantly masculine world of Springsteen, where women are rarely treated as sexual objects - save, perhaps, for Darlington Country (1984) - but traditional gender roles are maintained. Men are empowered, and women often powerless. The three articles in this section focus on different aspects of gender; however, the more interesting question of gender roles in Springsteen's music - alluded to in the title of the section Springsteen and Gender Identity - remains relatively unexamined in this collection. Another regularly occurring aspect is religious imagery, though Springsteen's music is resolutely a-religious. In an interview earlier this year, Springsteen joked that he, "got brainwashed as a child with Catholicism" (McCormick 
2012: web source). As Jeffrey Symynlywicz says, "If there is a 'religion' of Springsteen, then it is one that places great importance on individual freedom of belief" (2008: 180). It is appropriate then that the last section of this book contains four texts on Springsteen, ethics and social justice. These topic areas are considered and thoughtful, encompassing significant aspects of Springsteen's work.

Most of the articles are well-written, and a few are excellent. Cowie and Boehm's contribution on class provides an interesting study of the battle between the right and left for cultural possession of Springsteen's iconic Born in the U.S.A., using it as a vehicle to examine Springsteen's focus on and attitude toward the working class. Elizabeth Seymore's essay in the same section discusses the way "Springsteen either overtly or implicitly uses nostalgia to construct his working-class male characters" (63). Dividing his work into five periods, she constructs a strong argument for Springsteen's varying use of, and rationale for, nostalgia concluding that Springsteen's uses nostalgia to "come to terms with the realities of working-class Americans by applying a utopian vision of capitalism that perpetuates the same fundamental inequalities he criticises" (76). This is one of the more uncomfortable conclusions in the collection. Liza Zitelli's contribution from the second section examines the role of mothers within Springsteen's, Devils and Dust. The concept of 'home' is a central feature which Springsteen connects with concepts of motherhood (79). Zitelli argues that the patriarchal society - which much of Springsteen's work has celebrated - has meant both a loss of a relationship with 'home' and motherhood and yet an inability to let go of these images. Matthew Orel's chapter from the section on Springsteen and religion investigates the use of scriptural quotations in Springsteen's body of work. Springsteen has a somewhat irreverent attitude towards religion - one needs to look no further for evidence than the chorus of If I Were the Priest (1975). Orel argues convincingly that the imagery of early Springsteen songs uses more 'distorted' quotations (in which the original meaning is altered or misinterpreted) than the latter. He also includes a substantial compendium of religious references in Springsteen's book which forms a significant contribution to both his argument and to the topic of Springsteen and religion.

A few articles were less successful in developing a convincing argument. David Gellman's Darkness on the Edge of Town attempts to draw links such as topic areas and narratives between the author Richard Ford and Springsteen. He argues that the two influenced each other, a possible conclusion given the evidence, but the reader is left with the question "why Ford?" The two are near contemporaries (Ford is five years older) and similar parallels can thus be drawn with many artists of the period. Spencer Allen investigates the nine appearances of the term "promised land" in Springsteen's corpus. Allen (a theologian) concludes that this is a mistaken and popularist use of the term, equating it with "a dreamy, utopian paradise where the grass is greener than in the current oppressive/repressive location" (126). While this is undoubtedly true from a strictly Christian and Catholic stance, Springsteen is not delivering a sermon but performing a popular song that uses the promised land as an analogy in a popularist manner. The Promised Land (1977), central to Allen's argument (pp.137-139), contains a great deal of religious imagery. However, in another source Rob Kirkpatrick cites its origin in other areas including the Chuck Berry song Promised Land, Steinbeck's The Grapes of Wrath or John Ford's 1940 movie version (Kirkpatrick 2007: 58). Matthew Orel's treatment of this topic (147-148) is far more credible.

Springsteen has always been fascinating to popular music academics. His long career, his storytelling, his songwriting and his performance style is reflected by the many writings on him over the decades. Individual sources investigate aspects of his corpus, his politics (Masciotra 2010), his philosophy (Auxier and Anderson 2008) and his culture (Cullen 2005), but few have attempted such a sweeping contribution to the field. This alone makes the volume worthwhile, despite the somewhat variable strength 
of some of the articles. It is unarguably a significant addition to the body of writings about Springsteen.

\section{References}

Auxier, R. and Anderson, D. 2008. Bruce Springsteen and Philosophy: Darkness on the Edge of Truth. Carus Publishing, Peru, IL.

Cullen J. 2005. Born in the U.S.A.: Bruce Springsteen and the American Tradition. 2nd edition Wesleyan University Press, Middletown, CT.

Izzo, D. G. Bruce Springsteen and the American Soul: Essays on the Songs and Influence of a Cultural Icon. McFarland, Jefferson, NC.

Kirkpatrick, R. 2007. The Words and Music of Bruce Springsteen. Praeger Publishers, Westport CT.

McCormick, N. 2012, February 17. Bruce Springsteen: I enjoy artists who take on the world. The Telegraph Online. Retrieved from

http://www.telegraph.co.uk/culture/music/rockandpopmusic/9087360/BruceSpringsteen-l-enjoy-artists-who-take-on-the-world.html Accessed: 10 Jun 2013

Masciotra, D. 2010. Working on a Dream: The Progressive Political Vision of Bruce Springsteen. Continuum, New York.

Rhodes 2004. Utopia in Popular Management Writing and the Music of Bruce Springsteen: Do you Believe in the Promised Land? Consumption Markets and Culture. 7(1): 1-20.

Symynlywicz, J. 2008. The Gospel According to Bruce Springsteen: Rock and Redemption, from Ashbury Park to Magic. John Knox Books, Louisville KY.

\section{Discography}

Bruce Springsteen. 1984. "Darlington Country", Born in the U.S.A., Columbia.

Bruce Springsteen. 2005. Devils \& Dust, Columbia.

Bruce Springsteen. (unreleased). "If I Were The Priest".

Bruce Springsteen. 1977. "The Promised Land", Darkness on the Edge of Town, Columbia. 